\title{
Effectiveness assessment methodology financial processes in the digital economy
}

\author{
Andrey Mandrykin ${ }^{1, *}$ and Yulia Pakhomova ${ }^{1}$ \\ ${ }^{1}$ Voronezh State Technical University, Moscovskiy prospect 14, Voronezh, 394026, Russia
}

\begin{abstract}
In today's rapidly changing world, the application of the achievements of scientific and technological progress, the development and implementation of investment projects become a competitive advantage and the key to the successful development of regions, clusters, corporations. In some of the most dynamic industries, investing becomes a matter of not just efficient operation, but also determines the presence of companies in the market. Applied research, and even more so fundamental, requires significant investments, the return on which at the first stages of the development and implementation of investment projects is difficult to predict. The end result is also obviously not predictable, which makes investing one of the most risky areas of activity of modern companies. Therefore, today the development and improvement of investment efficiency are the most important tasks. The institutional and economic environment of developing countries may not be the positive effect expected from attracting enterprise investment. These ambiguous results regarding the impact of investment form the motivation and problem of dissertation research. Identifying and improving methodological and economic parameters for increasing investment efficiency in the electricity industry will always be one of the main tasks for owners of enterprises and managers, which determines the relevance of the study. The article developed a methodological approach to assessing the efficiency of investment projects in the electric power industry taking into account the risks taken into account in calculating the discount rate for each phase of the life cycle of the project, which allows you to more accurately calculate the main indicators of the efficiency of the investment project.
\end{abstract}

\section{Introduction}

Now, many problems of formation of investment process in modern conditions are caused by lack of accurately developed system of assessment of efficiency of investment policy. The system provides effective interaction of all levels of management, beginning from the enterprises and covering authorities of all levels [1]. It formulates these principles: principle of systemacity, principle of priority, principle of efficiency, principle of coherence and principle of control.

Main objective of formation of the portfolio of investments is implementation of the investment policy developed at the enterprise. At formation of the portfolio of investments

\footnotetext{
${ }^{*}$ Corresponding author: mandrykin@mail.ru
} 
the investor sets the following purposes:

- achievement of necessary level of profitability - receiving income from investments with the predetermined frequency;

- gain - is provided at investment of means which are characterized by increase in their cost in time;

- minimization of investment risks - increase in reliability of investments;

- ensuring sufficient liquidity of the invested means - fast address of investments into cash.

Assessment of main types of risks based on calculation of the general discount rate for all project is made for ensuring efficiency of the investment project [2].

\section{Materials and methods}

Currently, are used static, alternative and dynamic methods to assess the investment of enterprises.

The advantage of the statistical method is the simplicity of the calculation algorithm. The main disadvantage is the inability to estimate profitability after the payback period, as well as the inability to use it in calculating the efficiency of the project associated with the creation of the latest product.

The adjusted present value method allows you to divide the cash flow into several components, for which efficiency is estimated separately taking into account the cost of risk insurance, as well as subsidies and benefits allocated. This method is most effective for evaluating investment projects with multiple sources of financing.

The main disadvantage of the adjusted present value method is the need to study a significant amount of additional data. Calculated as NPV plus present value (PV) [4].

The value-added method allows you to estimate the profitability of investments that should exceed the weighted average value of capital. The main advantage of the method is the ability to determine the inefficient use of the funds of an investment project. The disadvantage is the inability to create a forecast for projects with complex cash flows with the need to take into account the time factor. It is calculated as the difference between the revenue from the sale of products and the cost of resources spent on production [5].

The real options method allows you to evaluate created or acquired investment objects over a long time. Calculated by formula (1):

$$
C \stackrel{I C *}{=} \frac{(P I-1)}{(1+r)^{t}}
$$

where $\mathrm{C}$ is the value of the real option;

IC - invested capital;

$\mathrm{r}$ - discount rate;

$t$ is the term of the option;

PI is the expected value of the profitability index.

The main advantage of the method is the ability to evaluate the entire project.

Dynamic methods are also called discounted, it follows that they are based on the theory of the time value of money [6].

The main indicators for assessing the effectiveness of investment projects dynamically are the net present value, the payback period of the project and the profitability index.

The criterion for evaluating the project is the net present value mark (NPV). If NPV $>0$, the project is accepted if NPV $<0$, the project is rejected [7].

Define the discount factor for the entire project. So, as a risk-free rate, we use a rate corresponding to the yield to maturity in 2018 of Russian Eurobonds. And as the values of risk premiums, we will take the expert estimates set out in the business plan of this project 
(Table 1).

Table 1. Calculation of the discount factor for the investment project in question

\begin{tabular}{|c|c|}
\hline Indicator name & measure value, $\%$ \\
\hline Risk-free rate & 7.52 \\
\hline \multicolumn{2}{|c|}{ Main types of project risks } \\
\hline Innovative risk & 10 \\
\hline Technical and technological risk & 5 \\
\hline Commercial risk & 2 \\
\hline Financial risk & 2 \\
\hline Country risk (included in risk-free rate) & 0 \\
\hline Total & $26.52 \%$ \\
\hline
\end{tabular}

We will determine the cost-effectiveness indicators of the investment project under consideration at the calculated discount rate (Table 2 - Table 4).

Table 2. Initial data for calculation, thousand RUB

\begin{tabular}{|c|c|c|c|c|c|c|c|c|}
\hline \multirow{2}{*}{$\begin{array}{l}\text { Description of } \\
\text { indicators }\end{array}$} & \multicolumn{8}{|c|}{ Period of investment project implementation } \\
\hline & 2019 & 2020 & 2021 & 2022 & 2023 & 2024 & 2025 & 2026 \\
\hline \multicolumn{9}{|c|}{ Concept Formation } \\
\hline Doinvestitsionny & $\begin{array}{l}20300 \\
0\end{array}$ & 0 & 0 & 0 & 0 & 0 & 0 & 0 \\
\hline $\begin{array}{l}\text { target market } \\
\text { analysis }\end{array}$ & 97000 & 0 & 0 & 0 & 0 & 0 & 0 & 0 \\
\hline \multicolumn{9}{|c|}{ Pre-investment calculations of revenues and expenses of the project, justification of its possible } \\
\hline expediency & 0 & $\begin{array}{l}370 \\
000\end{array}$ & 0 & 0 & 0 & 0 & 0 & 0 \\
\hline Development & 0 & $\begin{array}{l}450 \\
000\end{array}$ & 0 & 0 & 0 & 0 & 0 & 0 \\
\hline $\begin{array}{l}\text { Test costs of } \\
\text { experienced }\end{array}$ & 0 & $\begin{array}{r}38 \\
500 \\
\end{array}$ & 0 & 0 & 0 & 0 & 0 & 0 \\
\hline product samples & 0 & $\begin{array}{r}47 \\
000\end{array}$ & 0 & 0 & 0 & 0 & 0 & 0 \\
\hline Certification & 0 & $\begin{array}{r}35 \\
900\end{array}$ & 0 & 0 & 0 & 0 & 0 & 0 \\
\hline \multicolumn{9}{|c|}{ equipment } \\
\hline $\begin{array}{l}\text { Cost of design } \\
\text { and estimate }\end{array}$ & 0 & 0 & $\begin{array}{r}1230 \\
780 \\
\end{array}$ & $\begin{array}{l}1316 \\
935\end{array}$ & $\begin{array}{l}1409 \\
120\end{array}$ & $\begin{array}{r}1507 \\
758 \\
\end{array}$ & $\begin{array}{r}1613 \\
302\end{array}$ & 0 \\
\hline documentation & 0 & 0 & $\begin{array}{r}2030 \\
891 \\
\end{array}$ & $\begin{array}{l}2213 \\
671\end{array}$ & $\begin{array}{l}2412 \\
902\end{array}$ & $\begin{array}{r}2630 \\
063\end{array}$ & $\begin{array}{r}2866 \\
768\end{array}$ & 0 \\
\hline \multicolumn{9}{|c|}{ Calculations for feasibility study of investment } \\
\hline project & 0 & 0 & 0 & 0 & 0 & 0 & 0 & 450000 \\
\hline Costs of & 0 & 0 & $\begin{array}{r}2030 \\
891\end{array}$ & $\begin{array}{l}2213 \\
671\end{array}$ & $\begin{array}{l}2412 \\
902\end{array}$ & $\begin{array}{r}2630 \\
063\end{array}$ & $\begin{array}{r}2866 \\
768\end{array}$ & 0 \\
\hline $\begin{array}{l}\text { technical } \\
\text { supervision }\end{array}$ & $\begin{array}{l}300 \\
000\end{array}$ & $\begin{array}{l}941 \\
400\end{array}$ & $\begin{array}{r}1230 \\
780\end{array}$ & $\begin{array}{l}1316 \\
935\end{array}$ & $\begin{array}{l}1409 \\
120\end{array}$ & $\begin{array}{r}1507 \\
758\end{array}$ & $\begin{array}{r}1613 \\
302\end{array}$ & 450000 \\
\hline
\end{tabular}

Table 3. Calculation of net reduced project income (NPV), thousand rubles. 


\begin{tabular}{|c|c|c|c|c|c|c|c|c|}
\hline \multirow{2}{*}{$\begin{array}{l}\text { Description of } \\
\text { indicators }\end{array}$} & \multicolumn{8}{|c|}{ Period of investment project implementation } \\
\hline & 2019 & 2020 & 2021 & 2022 & 2023 & 2024 & 2025 & 2026 \\
\hline \multirow[t]{2}{*}{ Total revenue } & 0 & 0 & 2030 & 2213 & 2412 & 2630 & 2866 & 0 \\
\hline & & & 891 & 671 & 902 & 063 & 768 & \\
\hline \multirow[t]{2}{*}{ Total costs } & 300 & 941 & 1230 & 1316 & 1409 & 1507 & 1613 & 450 \\
\hline & 000 & 400 & 780 & 935 & 120 & 758 & 302 & 000 \\
\hline \multirow[t]{2}{*}{ Gross profit } & -300 & -941 & 800 & 896 & 1003 & 1122 & 1253 & -450 \\
\hline & 000 & 400 & 111 & 737 & 782 & 304 & 467 & 000 \\
\hline \multirow{2}{*}{ Income tax } & 0 & 0 & 160 & 179 & 200 & 224 & 250 & 0 \\
\hline & & & 022 & 347 & 756 & 461 & 693 & \\
\hline \multirow[t]{2}{*}{ Net profit } & -300 & -941 & 640 & 717 & 803 & 897 & 1002 & -450 \\
\hline & 000 & 400 & 089 & 389 & 025 & 843 & 773 & 000 \\
\hline \multirow{2}{*}{ Rate } & 26,52 & 26,52 & 26,52 & 26,52 & 26,52 & 26,52 & 26,52 & 26,52 \\
\hline & $\%$ & $\%$ & $\%$ & $\%$ & $\%$ & $\%$ & $\%$ & $\%$ \\
\hline discounting & 1,00 & 0,7904 & 0,6247 & 0,4938 & 0,3903 & 0,3085 & 0,2438 & 0,1927 \\
\hline Coefficient & $\begin{array}{r}-300 \\
000\end{array}$ & $\begin{array}{r}-744 \\
072\end{array}$ & 0 & 0 & 0 & 0 & 0 & 0 \\
\hline \multirow[t]{2}{*}{ discounting } & 0 & 0 & 399 & 354 & 313 & 276 & 244 & -86 \\
\hline & & & 873 & 223 & 395 & 952 & 482 & 716 \\
\hline Initial & \multicolumn{8}{|c|}{458138} \\
\hline
\end{tabular}

Table 4. Calculation of NPV for determination of internal rate of return (IRR), thousand rubles.

\begin{tabular}{|l|r|r|r|r|r|r|r|r|}
\hline \multirow{2}{*}{$\begin{array}{l}\text { Description of } \\
\text { indicators }\end{array}$} & \multicolumn{7}{|c|}{ Period of investment project implementation } \\
\cline { 2 - 10 } & 2019 & 2020 & 2021 & 2022 & 2023 & 2024 & $\begin{array}{l}2025 \\
\Gamma .\end{array}$ & $\begin{array}{r}2026 \\
\Gamma .\end{array}$ \\
\hline Total revenue & 0 & 0 & 2030 & 2213 & 2412 & 2630 & 2866 & 0 \\
& & & 891 & 671 & 902 & 063 & 768 & \\
\hline Total costs & 300 & 941 & 1230 & 1316 & 1409 & 1507 & 1613 & 450 \\
& 000 & 400 & 780 & 935 & 120 & 758 & 302 & 000 \\
\hline Gross profit & -300 & -941 & 800 & 896 & 1003 & 1122 & 1253 & -450 \\
& 000 & 400 & 111 & 737 & 782 & 304 & 467 & 000 \\
\hline Income tax & 0 & 0 & 160 & 179 & 200 & 224 & 250 & 0 \\
& & & 022 & 347 & 756 & 461 & 693 & -450 \\
\hline Net profit & -300 & -941 & 640 & 717 & 803 & 897 & 1002 & 000 \\
\hline Rate & 000 & 400 & 089 & 389 & 025 & 843 & 773 & $\%$ \\
& 45,00 & 45,00 & 45,00 & 45,00 & 45,00 & 45,00 & 45,00 & 45,00 \\
\hline discounting & 1,00 & 0,6897 & 0,4756 & 0,3280 & 0,2262 & 0,1560 & 0,1076 & 0,0742 \\
\hline Coefficient & -300 & -649 & 0 & 0 & 0 & 0 & 0 & 0 \\
\hline discounting & 000 & 241 & & & & & & $\%$ \\
\hline Initial & 0 & 0 & 304 & 235 & 181 & 140 & 107 & -33 \\
\hline
\end{tabular}

\section{Results}

Thus, as a result of the calculations, we obtain the value of IRR $=44.48 \%$.

Also, using the formula (4), we calculate the investment profitability index PI $=1.44$.

Table 5. Calculation of the payback period of the investment project (PP), thousand rubles. 


\begin{tabular}{|c|c|c|c|c|c|c|c|c|}
\hline \multirow{2}{*}{$\begin{array}{l}\text { Name } \\
\text { indicators }\end{array}$} & \multicolumn{8}{|c|}{ Project Implementation Period } \\
\hline & 2019 & 2020 & 2021 & 2022 & 2023 & 2024 & 2025 & 2026 \\
\hline Initial investments & $\begin{array}{r}-300 \\
000\end{array}$ & $\begin{array}{r}-649 \\
241\end{array}$ & 0 & 0 & 0 & 0 & 0 & 0 \\
\hline Real value & 0 & 0 & $\begin{array}{l}399 \\
873\end{array}$ & $\begin{array}{l}354 \\
223\end{array}$ & $\begin{array}{l}313 \\
395\end{array}$ & $\begin{array}{l}276 \\
952\end{array}$ & $\begin{array}{l}244 \\
482\end{array}$ & $\begin{array}{r}-86 \\
716 \\
\end{array}$ \\
\hline NPV cumulative & $\begin{array}{r}-300 \\
000\end{array}$ & $\begin{array}{r}-949 \\
241\end{array}$ & $\begin{array}{r}-549 \\
369\end{array}$ & $\begin{array}{l}-195 \\
145\end{array}$ & $\begin{array}{l}118 \\
250\end{array}$ & $\begin{array}{l}395 \\
202\end{array}$ & $\begin{array}{l}639 \\
685\end{array}$ & $\begin{array}{l}552 \\
969\end{array}$ \\
\hline result & & & & & & & & \\
\hline
\end{tabular}

Let us present in general the calculated indicators of economic efficiency of this project (Table 6).

Table 6. Performance indicators of investment project in conditions of total discount rate

\begin{tabular}{|l|r|}
\hline Indicator name & value \\
\hline Discount rate for project, $\%$ & $26.52 \%$ \\
\hline Project net discounted income (NPV), thousand rubles & 458138 \\
\hline Internal rate of return (IRR), $\%$ & $44.48 \%$ \\
\hline Profitability Index (PI) & 1.44 \\
\hline Project Payback Period (PP), Year & 3.93 \\
\hline
\end{tabular}

Thus, in order to justify the effectiveness of the author's methodology for evaluating this project taking into account the main types of risks, the following steps were taken to determine the feasibility of investing in the project and confirm the effectiveness of the proposed evaluation approach [8].

The inflows and outflows were structured according to the project under consideration, after which all the data are summarized in the general table 7. 


\section{Discussion}

To carry out the third to fifth phase of the proposed approach to assessing the effectiveness of the investment project under consideration, calculated discount ratios were used and cash flows and outflows were converted to current value, as well as project performance indicators were calculated (Table 9 - Table 11).

Table 9. Calculation of discount rate for each project phase

\begin{tabular}{|l|l|r|}
\hline Indicator name & Risks used & Value \% \\
\hline Discount rate for phase & Innovative risk & $17.52 \%$ \\
\hline shaping the concept & $\begin{array}{l}\text { Innovative risk, technical } \\
\text { and technological risk, }\end{array}$ & $24.52 \%$ \\
\hline & financial risk & $14.52 \%$ \\
\hline Discount rate for development phase & $\begin{array}{l}\text { technical and } \\
\text { technological risk, }\end{array}$ & $9.52 \%$ \\
\hline
\end{tabular}

Table 10. Calculation of net present income (NPV), thousand rubles.

\begin{tabular}{|c|c|c|c|c|c|c|c|c|}
\hline \multirow{2}{*}{$\begin{array}{l}\text { Description of } \\
\text { indicators }\end{array}$} & \multicolumn{8}{|c|}{ Period of investment project implementation } \\
\hline & 2019 & 2020 & 2021 & 2022 & 2023 & 2024 & 2025 & 2026 \\
\hline Total revenue & 0 & 0 & $\begin{array}{r}2030 \\
891\end{array}$ & $\begin{array}{r}2213 \\
671\end{array}$ & $\begin{array}{r}2412 \\
902\end{array}$ & $\begin{array}{r}2630 \\
063\end{array}$ & $\begin{array}{r}2866 \\
768\end{array}$ & 0 \\
\hline Total costs & $\begin{array}{l}300 \\
000\end{array}$ & $\begin{array}{l}941 \\
400\end{array}$ & $\begin{array}{r}1230 \\
780\end{array}$ & $\begin{array}{r}1316 \\
935\end{array}$ & $\begin{array}{r}1409 \\
120\end{array}$ & $\begin{array}{r}1507 \\
758\end{array}$ & $\begin{array}{r}1613 \\
302\end{array}$ & $\begin{array}{l}450 \\
000\end{array}$ \\
\hline Profit & $\begin{array}{r}-300 \\
000 \\
\end{array}$ & $\begin{array}{l}-941 \\
400 \\
\end{array}$ & $\begin{array}{l}800 \\
111 \\
\end{array}$ & $\begin{array}{l}896 \\
737 \\
\end{array}$ & $\begin{array}{r}1003 \\
782 \\
\end{array}$ & $\begin{array}{r}1122 \\
304 \\
\end{array}$ & $\begin{array}{r}1253 \\
467 \\
\end{array}$ & $\begin{array}{r}-450 \\
000 \\
\end{array}$ \\
\hline gross & 0 & 0 & $\begin{array}{l}160 \\
022\end{array}$ & $\begin{array}{l}179 \\
347\end{array}$ & $\begin{array}{l}200 \\
756\end{array}$ & $\begin{array}{l}224 \\
461\end{array}$ & $\begin{array}{l}250 \\
693\end{array}$ & 0 \\
\hline Tax on & $\begin{array}{r}-300 \\
000\end{array}$ & $\begin{array}{l}-941 \\
400\end{array}$ & $\begin{array}{l}640 \\
089\end{array}$ & $\begin{array}{l}717 \\
389\end{array}$ & $\begin{array}{l}803 \\
025\end{array}$ & $\begin{array}{l}897 \\
843\end{array}$ & $\begin{array}{r}1002 \\
773 \\
\end{array}$ & $\begin{array}{r}-450 \\
000\end{array}$ \\
\hline profit & $\begin{array}{r}17,52 \\
\%\end{array}$ & $\begin{array}{r}24,52 \\
\%\end{array}$ & $\begin{array}{r}14,52 \\
\%\end{array}$ & $\begin{array}{r}14,52 \\
\%\end{array}$ & $\begin{array}{r}14,52 \\
\%\end{array}$ & $\begin{array}{r}14,52 \\
\%\end{array}$ & $\begin{array}{r}14,52 \\
\%\end{array}$ & $9,52 \%$ \\
\hline Net profit & 1,00 & 0,8031 & 0,7625 & 0,6658 & 0,5814 & 0,5077 & 0,4433 & 0,5291 \\
\hline Rate & $\begin{array}{r}-300 \\
000 \\
\end{array}$ & $\begin{array}{l}-756 \\
023 \\
\end{array}$ & 0 & 0 & 0 & 0 & 0 & 0 \\
\hline discounting & 0 & 0 & $\begin{array}{l}488 \\
065 \\
\end{array}$ & $\begin{array}{l}477 \\
651 \\
\end{array}$ & $\begin{array}{l}466 \\
878 \\
\end{array}$ & $\begin{array}{l}455 \\
821 \\
\end{array}$ & $\begin{array}{l}444 \\
544 \\
\end{array}$ & $\begin{array}{r}-238 \\
099 \\
\end{array}$ \\
\hline Coefficient & & & & 103 & 837 & & & \\
\hline
\end{tabular}

To calculate the IRR, take the average discount rate for the project, equal to $16.52 \%$. Using the data of Table 10 and formula (16) we obtain IRR $=44.64 \%$

Let's calculate the investment profitability index PI $=1.98$. Table 17 shows the calculation of the payback period of the investment project.

Table 11. Calculation of the project payback period (PP), thousand rubles.

\begin{tabular}{|l|r|r|r|r|r|r|r|r|}
\hline $\begin{array}{l}\text { Description } \\
\text { of indicators }\end{array}$ & \multicolumn{7}{|c|}{ Project Implementation Period } \\
\cline { 2 - 9 } & 2019 & 2020 & 2021 & 2022 & 2023 & 2024 & 2025 & 2026 \\
\hline Initial & -300 & -756 & 0 & 0 & 0 & 0 & 0 & 0 \\
& 000 & 023 & & & & & & \\
\hline
\end{tabular}




\begin{tabular}{|l|r|r|r|r|r|r|r|r|}
\hline investments & 0 & 0 & 488 & 477 & 466 & 455 & 444 & -238 \\
& & & 065 & 651 & 878 & 821 & 544 & 099 \\
\hline Real & & & & & & & & \\
& -300 & -1056 & -567 & -90 & 376 & 832 & 1276 & 1038 \\
& 000 & 023 & 958 & 307 & 571 & 392 & 936 & 837 \\
\hline cost & \multicolumn{8}{|c|}{3,19} \\
& \multicolumn{10}{|c|}{} \\
\hline
\end{tabular}

We will present in general form the calculated indicators of economic efficiency of the evaluated investment project according to the proposed methodology of accounting for the main types of project risks (Table 12).

Table 12. Project performance indicators calculated according to the proposed methodology

\begin{tabular}{|l|r|}
\hline Indicator name & \multicolumn{2}{|c|}{ value } \\
\hline $\begin{array}{l}\text { Project net discounted income (NPV), thousand } \\
\text { rubles }\end{array}$ & 1038837 \\
\hline Internal rate of return (IRR),\% & $44.64 \%$ \\
\hline Profitability Index (PI) & 1.98 \\
\hline Project Payback Period (PP), Year & 3.19 \\
\hline
\end{tabular}

\section{Conclusion}

In order to identify the impact of the proposed approach to assessing the effectiveness of the investment project taking into account the main types of risks, we will carry out an analytical comparison of the calculated efficiency indicators according to the author's methodology with indicators of the project economic efficiency calculated according to the general methodology, and we will present quantitative and qualitative changes in Table 13.

Table 13. Comparison of changes in the investment project performance indicators depending on the evaluation algorithm

\begin{tabular}{|l|r|r|}
\hline \multirow{2}{*}{$\begin{array}{l}\text { Name } \\
\text { discounted cash flow }\end{array}$} & $\begin{array}{l}\text { measure value } \\
\text { calculated with total } \\
\text { risk, at the total } \\
\text { discount rate for the } \\
\text { project }\end{array}$ & $\begin{array}{l}\text { calculated with more } \\
\text { complete consideration of the } \\
\text { risks of the project, according } \\
\text { to the proposed methodology }\end{array}$ \\
\hline $\begin{array}{l}\text { Project net discounted income } \\
\text { (NPV), thousand rubles }\end{array}$ & 458138 & 1038837 \\
\hline Profitability Index (PI) & 1.44 & 1.98 \\
\hline Internal Rate of Return (IRR), \% & 44.48 & 34.64 \\
\hline Project Payback Period (PP), Year & 3.93 & 3.19 \\
\hline
\end{tabular}

Thus, having conducted a comparative analysis of changes in the performance indicators of the analyzed project (quantitative and qualitative) presented in Table 13, it should be said that due to the application of the proposed approach to assessing the effectiveness of the investment project taking into account the main types of risks at the enterprise, it was possible to significantly increase the accuracy of calculations of the forecast values of the implemented project, namely, net discounted project income (NPV) increased by $126.75 \%$.

When implementing the proposed approach to assessing the effectiveness of the investment project, UEMZ JSC will significantly increase the accuracy of forecast calculations [9]. This has contributed to more effective risk management, which will significantly reduce the uncertainty regarding the decision on whether to invest and the 
further implementation of the investment project, which is a clear argument for Investor in favour of choosing this approach to assess the effectiveness of the project in question [10]. Thus, risks are associated with postponing the implementation of the investment project over time, therefore, taking into account uncertainty should be an integral part of the assessment of the effectiveness of projects. When creating and implementing an investment project, it is necessary to take into account innovative, commercial, technical and technological, financial risks. Therefore, it is proposed to improve the methodology for assessing efficiency based on the risks taken into account in calculating the discount rate for each phase of the life cycle of the project [11].

\section{References}

1. Decree of the President of the Russian Federation dated 01.12.2016 N 642 "On the Strategy for the Scientific and Technological Development of the Russian Federation Consultant Plus http://www.consultant.ru/document/cons_doc_LAW_207967/ (Last accessed 15.08.2018)

2. S. D. Bodrunov, The Fourth Industrial Revolution is a prologue of the New Industrial Society of the second generation//Scientific works of the Free Economic Society of Russia, 205, 262-284 (2017)

3. O. P. Pidyashova, Assessment of investments in modern conditions//Economics: yesterday, today, tomorrow, 7, 170-179 (2016)

4. E. E. Dosuzheva, Yu. V. Kirillov, Basic principles of implementation of the investment project Science, 1, 13 (2016)

5. A. Golyashev, Investments and sources of their financing//Bulletin on the current trends of the Russian economy, 17, September (2016)

6. E. G. Lyubovtseva, On financing investments of the Chuvash Republic, Science, 9(2), 2112017

7. A. I. Shabieva, A. G. Korolev, D. V. Shchegelsky, Investment policy in industrial corporations, Academic Bulletin, 195-198 (2012)

8. A. G. Brusov, I. A. Brusova, Evaluation of the efficiency of investment projects taking into account multifactorial costs and results, Increasing the competitiveness of economic sectors as a way out of the economic crisis: Sat. materials of international scientific and practical, 417- 420 (Cheboksary, Publishing House Chuvash. un-ta, May 11-12, 2016)

9. N. A. Akhmedov, Methodological basis of development of strategy of promising investment policy of economic growth of enterprises, Transport business of Russia, 31$36(2015)$

10. O. M. Malshchukova, Problems of development of enterprise investment policy, Issues of innovation economy, 29-38 (2017)

11. S. A. Ogarkov, Improving investment in agricultural fixed assets: monograph, 59 (Moscow, OntoPrint, 2018)

12. V. A. Zimin, Basic principles and methods of forming the investment portfolio of the enterprise. Theory and practice of social development, 227-229 (2016)

13. Law of the Russian Federation No. 39 dated February 25, 1999 "On investment activities in the Russian Federation carried out in the form of capital investments."

14. Law of the RSFSR No. 1488-1 of the Federal Law of June 26, 1991 "On Investment Activities in the RSFSR." 
15. Methodological recommendations for assessing the effectiveness of investment projects. Official publication (Moscow, 2015)

16. G. P. Oksyutik, Foreign investments in Russia: monograph. - St. Petersburg: Publishing House of St. Petersburg University of Management and Economics, 79 (2016)

17. S. N. Yashin, N. I. Yashina, E. V. Koshelev, Financing of innovations and investments of enterprises: Monograph, 41 (Nizhny Novgorod: Publishing House of VGIPU, 2015)

18. A. I. Mantikova, I. I. Mantikova, Assessment of the economic efficiency of investment projects. Scientific community of students of the 21 st century. Economic sciences: sb. Art. By mat. XXI international student. Scientific. - Prakt. Conf., 6(21)

19. Decree of the President of the Russian Federation dated 01.12.2016 N 642 "On the Strategy for the Scientific and Technological Development of the Russian Federation " Consultant Plus. http://www.consultant.ru/document/cons_doc_LAW_207967/ (Last accessed 15.08.2018)

20. A. A. Alekseev, Modern priorities of the state policy of improving the efficiency of the Russian economy: innovative aspects: dis. Dr. Econ. sciences. Novosibirsk (2016)

21. P. A. Arkin, K. A. Soloveichik, V. P. Borodina, Architecture of finance: organizational mechanism of interaction between financial and real sectors, News of St. Petersburg State University of Economics, 1, 19-25 (2015)

22. A. O. Blinov, Innovative entrepreneurship, ed. V. Ya. Gorfinkel, T. G. Popadyuk., 523 (Moscow, Yurite, 2017)

23. A. Baranov, On application of IFRS provisions and possibilities of using Basel recommendations to assess market risk of Russian NPFs, Securities market, 10, 31-39 (2015)

24. I. A. Blank, Form Investment management: training course, 2nd, rework. and additional (Kiev: Nika-Center: Elga, 2016) 